\title{
Determinants of Capital Structure: Evidence from Jordan
}

\author{
Sufian Radwan Almanaseer ${ }^{1}$ \\ ${ }^{1}$ Business Economic Department, Business Faculty, Tafila Technical University, Jordan \\ Correspondence: Sufian Radwan Almanaseer, P. O. Box 179, Tafila 66110, Jordan. E-mail: \\ sufian.r.manaseer@gmail.com
}

Received: April 22, 2019

Accepted: October 27, 2019

Online Published: November 5, 2019

doi:10.5430/afr.v8n4p186

URL: https://doi.org/10.5430/afr.v8n4p186

\begin{abstract}
This study aimed to explore the determinants of the capital structure of the banks listed in the Amman Stock Exchange. A sample of 13 Jordanian commercial banks of 16 banks listed on the Amman Stock Exchange selected for the period 2008-2017. The current study applied a fixed-effects regression model by using e-views to analyze the relationship between financial leverage and firm characteristics such as Risk, Size, profitability, Growth, liquidity, Tax, Age, tangibility, and macroeconomic variables such as Gross Domestic Product, Inflation. The study finds a significant positive relationship between financial leverage, age, growth, risk, size, and tax. Also, the study finds a significant negative relationship between financial leverage with GDP, inflation, liquidity, profitability, and tangibility.
\end{abstract}

Keywords: firm size, firm growth, tax, firm risk, firm age, profitability, liquidity, tangibility, gross domestic product, inflation, financial leverage

\section{Introduction}

Diamond and Rajan (2000) stated that the bank's capital structure affected its capacity to provide liquidity and credit effectively. Though all firms are similar in a term of the necessity for the capital to support their varied processes and achieve the progression in their work, still there is a difference among these banks in their activities which aim to fulfil multiple and contradictory requirements at the same time providing liquidity for depositors on-demand and grant credit for borrowers (Kashyap et al., 2002). Thus, the banks' success depends on their ability to determine test and manage accurately the risks, so the banks should care about solvency and liquidity. This helps to adapt correct methods in determining the suitable size of capital to confront unexpected losses caused by different risks. Houston et al. (1997) stressed that major banks are less vulnerable to changes in their capital. Akhavein et al. (1997) referred that big bank after mergers decrease capital and raise the rate of lending.

According to our review of previous studies, many studies have discussed the determinant of capital structure in different companies in different countries. However, according to the researcher's knowledge, there are not enough studies on the determinant of the capital structure of Jordanian banks to understand how Jordanian banks have chosen the capital structure.

Therefore, the importance of this study shown as a complementary value too many previous studies in Jordan in understanding the capital structure determinants in Jordanian banks, on which the government relies to manage the development and prosperity movement and play a vital role in providing non-financial institutions with the required funds, and in implementing monetary policy, and the stability Economy. Also, the results are expectant to be beneficial to bank departments, shareholders, investors, creditors, financial analysts, and the central bank.

The paper is organized as follows. First, it presents a literature review of the capital structure. Second, it explores the theoretical framework and previous studies. Third, hypotheses, population, the sample, data collection, the mathematical model, variables measuring. Fourth, the statistical analysis and discuss the results. Finally, conclusions, limitations, and recommendations.

\section{Theoretical Part and Related Studies}

In this part, it will review the theoretical studies that discussed the capital structure. Then, clarifications about the firm characteristic such as firm size 'growth in assets 'tax ‘firm risk ‘firm age 'profitability ‘liquidity 'tangibility, and the macroeconomic variables such as Gross Domestic Product and Inflation. 


\subsection{Theories of Capital Structure}

1. Modigliani and Miller Theory (1958 and 1963): This theory specializes in studying the financial structure of the firm and its relationship with the cost of money considering assuming a perfect capital market. This theory includes two suggestions: first one if there are no taxes, and bankruptcy cost, management cost, differing information, and market efficiency, the firm value will not be an effect of financing either by issuing shares or debt, i.e. the firm capital structure is irrelevant to the financial leverage. The other suggestion stated that the financial leverage of the firm does not influence the weighted average cost of capital (WACC). Fama and French (2002) stated in their study about the tax model in Modigliani and Miller theory that the most profitable firms used more debt rather than equity.

2. The Agency Cost Theory: This theory showed that the management cost for managing institutions on behalf of their owners might lead to a kind of incompetent administrations which work and choose the income and the outcome, according to their desires; this might cause a failure in maximizing the firm's value. The influence of the external cost equals the loss or the drop in the firm value caused by the administrations that only care about maximizing their private benefits instead of the firm value. (Jensen and Meckling, 1976; Myers, 2001; Harris and Raviv, 1991) referred to the fact that choosing the useful capital structure might help in ditching such cost. The theory claimed that raise in the financial leverage or a drop in the ratio of equity might lead to lower the costs of firms which caused by the external financing in one hand, and to increase the firm value through encouraging the administrations to work hard to maximize the firm's earnings and fulfilling the owners' goals that represented in increasing the earnings. Grossman and Hart (1982) showed that the increase in financing by debt might cause a positive impact on managers and a drop in the firm cost through lowering the cost of the external financing represented by maximizing the firm's earnings and providing the liquidity to pay the firm liabilities on time. And, the company can negotiate to get low-cost loans with concessional terms. (Harris and Raviv, 1990; Stulz, 1985) stated that banks saved personal and secret information about their clients and their partners in lending, and working to provide the government guarantees which increase the banks' cost concerning the external debt.

3. The Trade-Off Theory: This theory assumed a positive relationship between taxes and financial leverage; one of the tax features is the increase in using debt, which, as a result, increases the owners' earnings. Hence, the theory assumes an optimal ratio of debt to equity, so the firms tried to balance between the benefits of debt taxes and the risk of bankruptcy. The theory suggests that the firm can achieve its goals concerning financial leverage through taxes, the cost of bankruptcy and conflict of interests between creditors and owners. Ooi (1999) referred, according to the tax trade-off model, that the successful firms will use more debt because they possibly have a high tax cost and low bankruptcy risks, so the taxes will increase taxes paid on the debt through tax shield and increase the internal cash flow in the firm after taxes; There is a positive relationship between tax protection and firm value. Concerning the bankruptcy cost, Cassar and Holmes (2003) pointed out that firms will afford high financing costs due to potential liquidation costs in case of bankruptcy, i.e. the higher the probability of the company defaulting on its debt to over zero, and the decline in its revenues, which will force it to Bankruptcy and liquidation of its assets. In case a firm increases its debts to finance the activities, it might disable to repay the debts on time, which causes the risk of bankruptcy, liquidation, which will force them to move to the debt holders, where if of bankruptcy will appear the opportunity cost. Besides bankruptcy, the institution usually loses its clients because of fear of failure to provide services and the risk of trusting the institution (Kochhar, 1997).

4. Pecking Order Theory: According to (Myers, 1984; Myers and Majluf, 1984) who developed this theory, firms prefer specific choices concerning the used capital to finance its activities because of the difference in the cost of these sources. Thus, the financial sources for the firms are a list within the following three sources: the internal finance based on the money generated from profits, financed by debt and financed by new shares. The priority in financing, according to this theory is firstly by the internal finance, then the finance with debt and lastly finance with new shares; firms should adhere to this hierarchical order in choosing their financial sources and financing by new shares should be the last one as this source brings new owners of the firm and affects deciding (Brealey and Myers, 2003). Hutchinson and Mengersen (1989) stated that the high growth firms showed similar financial and operating features, while companies with a high probability of insolvency suffer from reduced or discontinued stakeholders and clients from dealing with them for fear of being at risk of being unable to meet their obligations to them, leading to a decline in the company's value. Therefore, the company will reduce financing by debt to reduce these costs, and this will ultimately influence the company's operations and the company's capital structure.

5. Market Timing Theory: The first to mention this is (Myers and Majluf, 1984) assuming that there are rational managers and investors. The theory focused on how firms finance their investments, either by shares or debt instruments, in line with market timing. Managers believe they can figure out the right time in the market to issue 
shares if they think there is a rise in stock prices, and the right time to buy back if they think there is a drop in stock prices. This leads to a poor assessment by managers because of information inconsistency between managers and investors. Graham and Harvey (2001) noted that the continuing impact of market timing on the capital structure is unclear.

\subsection{Previous Studies}

Since Modigliani and Miller theory $(1958,1963)$, the capital structure has been the focus of research, with several studies conducted for different sectors in different countries.

First, Omet and Mashharawe (2003) in their study (The Capital Structure Choice in Tax Contrasting Environments: Evidence from the Jordanian, Kuwaiti, Omani, and Saudi Corporate Sectors) for the period 1996-2001. The study found that there is a positive and statistically significant effect of both size and tangibility on financial leverage, while there is a statistically significant negative effect of both profitability and liquidity on the financial leverage, but there is a positive effect that is not statistically significant for growth on leverage.

Siam et al. (2005) in their study (The Capital Structure of Banking Sector in Jordan) on 12 Jordanian commercial banks listed in the Amman Stock Exchange for the period 1992-2001. The study found that there is a positive and statistically significant relationship between bank size and profitability with the leverage, while there is a negative and statistically significant relationship between the liquidity ratio and leverage. However, there is a positive relationship that is not statistically significant between the age of the bank and financial leverage.

In the same field, Amidu (2007) studied this topic in the study titled (Determinants of capital structure of banks in Ghana: An empirical approach) on 19 banks listed in Ghana Bursa for the period 1998-2003. The study found a negative relationship between profitability and leverage, while there was a positive relationship between size, tax, and growth with leverage. There is a positive relationship that is not statistically significant between risk and leverage.

Similarly, Ramadan and Alokdeh (2011) in their study titled (Determinants of Capital Structure: Evidence from Jordan 2000-2006) for the period 2000-2006. The study found that there was a statistically and economically negative relationship between profitability, liquidity, asset structure, risks of the company and capital structure. But there was no evidence for a relationship between the age, expected growth and tax shield of the company and capital structure.

Al-Qudah (2014) in the study titled (the determinants of capital structure of listed banks in Jordan: panel data analysis) for the period 2006-2010. The study showed a statically significant positive effect of size and profitability on financial leverage. The study also showed that the Jordanian bank-financed $70 \%$ of their assets through deposits.

Al-Singlawi and Aladwan (2016) in the study titled (Company's characteristics and capital structure: An Empirical Study on Listed Insurance Companies in Jordan) for the period 2010-2014. The study showed a significant negative relationship between capital structure and the firm's growth, profitability, size, and risk. While the capital structure has a positive significant relationship with tangibility.

Mota, J.H.F. \& Moreira, A.C. (2017) in the study titled (Determinants of the capital structure of Portuguese firms with investments in Angola) for the period 2006-2010. The study showed that asset structure, age, and tangibility have a positive effect on the capital structure, while liquidity and non-debt tax shields have a negative effect on leverage.

V. Ilyukhin (2017) in his study (The Determinants of Capital Structure: Evidence from Russia) for the period 2009-2015. The study found that business risk, firm size, and inflation rate had a positive relationship to all leverage ratios. While profitability, growth opportunities had a negative relationship with all leverage ratios. The tangibility of assets had a mixed relationship to leverage ratios. The tax expense did not have a statistically significant relationship with leverage ratios.

Akgul and Sigali (2018) in their study (Determinants of Capital Structure: An Application on BIST Transportation Index) for the period 2002-2013. The study results show that size has a significant positive relationship with leverage, while tangible assets have an insignificant positive relationship with leverage. However, liquidity, profitability has a significant negative relationship with leverage.

Kiraci and Aydin (2018) in their study (Determinants of Capital Structure: Empirical evidence from traditional airlines) for the period 2004-2015. The study results show that asset structure and size have a positive influence on long-term debt but a negative influence on short-term debt. Also, growth opportunities have a negative influence on the total debt ratio.

What distinguishes this study from previous studies? First, the previous studies focused on the study of the capital structure in the industrial companies or insurance companies, while this study focused on Jordanian commercial banks, where according to the researcher's knowledge there are not enough studies on the determinants of the capital 
structure in the Jordanian commercial banks. Second, the previous studies focused on some variables related to the characteristics of the company while ignoring macroeconomic variables, while this study includes more variables related to the characteristics of the company such as the size of the company and the growth in assets and tax rates and the risks of the company and the age of the company and profitability and liquidity and the structure of assets, besides several economic variables Aggregates such as GDP and inflation. Finally, according to the researcher's knowledge, no study has been conducted regarding the determinants of the capital structure in the Jordanian commercial banks for the period 2008-2017, which is a good period to reach logical results while the previous studies covered 4-6 years.

\subsection{Firm Characteristics}

1. Firm Size: The small firms rely on debt to fulfill their obligations because of their low capabilities in reaching the capital markets, and, lending small firms include a high risk compared to big firms, this assured the negative relationship between firm size and bankruptcy. (Smith and Warner, 1979; Ang and McConnel, 1982) showed that big firms have a low possibility of bankruptcy because of the variety they have in comparison with small firms. By reviewing the findings of the previous studies (Kester, 1986; Lasfer, 1999; Barclay et al., 1995), there was a positive relationship between firm size and financial leverage. Also, Michaelas et al. (1999) referred to a positive relationship between size and debt maturity structure of firms. While, (Marsh, 1982; Titman and Wessels, 1988) stated that there is a negative relationship between the ratio of debt and firm size.

2. Assets Growth: Pecking order theory showed that companies with high growth rates have the high utilization of funds generated from their internal sources, they will, therefore, seek external sources of funding to finance their growth. These firms prefer short-term, low-risk debt rather than long-term, high-risk debt. (Auerbach, 1985) pointed out that there was a negative relationship between growth rate and financial leverage because of usually having non-debt tax shields. Michaelas et al. (1999) found a positive corrlelation between growth rate, financial leverage, and long-term debt.

3. Tax: (Auerbach, 1985; MacKie-Mason, 1990) pointed out that changes in tax rate affected the decision to choose debt financing or equity. Ashton (1991) noted a weak relationship between debt use and tax shield. Graham (1996) noted that taxes mostly had no effect on financing decisions.

4. Firm Risk: (Titman and Wessels, 1988; Ooi, 1999) pointed to the existence of a negative relationship between risk and leverage. The more volatile the company profits, the higher the likelihood of default, agency costs, and bankruptcy. In addition, companies with high operational risk will have less leverage than fixed-income companies.

5. Firm Age: (Green et al., 2002; Ramadan and Alokdeh, 2011) show that there is no evidence of a correlation between the capital structure and the firm age, they consider the firm age as an indicator of its reputation and capability for progression. Younger companies also need more loans to finance their growth because of lower profits.

6. Profitability: (Modigliani and Miller, 1963; Ooi, 1999) showed that high-profit firms would use more debt because of their lower risk of bankruptcy and a high tax burden. But (Myers, 1984; Titman and Wessels, 1988; Barton et al., 1989; Chittenden et al., 1996; Coleman and Cole, 1999; Al-Sakran, 2001) pointed to a negative relationship between debt and profitability, so that high-profit firms will have a low debt rate because it will rely on its internal sources instead of external sources to get the funds.

7. Liquidity: (Jong et al., 2007; Alzubaidi and Salameh, 2014) showed that there is a negative relationship between the liquidity ratio and the leverage, the firms with higher liquidity ratio, the higher its ability to pay its obligations resulting in lower risk, and will not resort to borrowing to finance operations growth has. Ozkan (2001) pointed out that liquidity has a double impact on the firm's financial structure, where the relationship between the liquidity ratio and debt may negative or positive, that firms with high liquidity ratio will have a high capability to fulfill their obligations, which may have to resort to borrowing In case they need to finance their growth, this shows a positive relationship between the liquidity ratio and the debt, while other firms may use liquidity to finance growth processes instead of borrowing which leads to a low debt, this shows a negative relationship between the liquidity ratio and the debt.

8. Tangibility: Pecking Order Theory and trade-off theory, and (Van der Wijst and Thurik, 1993; Chittenden et al., 1996; Michaelas et al., 1999), showed a positive relationship between asset structure and leverage. (Myers, 1977) noted that fixed assets support getting more debt, which contributes to the growth process. (Harris and Raviv, 1991; Titman and Wessels, 1988) pointed out that the higher the tangible assets in a company, the higher its ability to repay debts if of liquidation. Smith and Warner (1979; Stulz and Johnson, 1985) also noted that assets could collateral to reduce agency costs associated with debt use. (Feri and Jones, 1979; Marsh, 1982; Long and Matlitz, 1985; and Allen, 1995) showed a positive relationship between fixed assets and the debt ratio. 
9. Gross Domestic Product: Trade-off theory and Gropp and Heider (2010) showed a positive relationship between GDP and financial leverage. Gatsi (2012) also pointed out that GDP is an important macroeconomic factor affecting banking activities. Since, during booms, the demand for borrowing from banks to meet different needs will increase, while during a recession, the firms will hesitate to borrow because of rising bankruptcy costs. (Booth et al., 2001; Gropp and Heider, 2010) showed a positive relationship between GDP and financial leverage. However, Nguyen and Kayani (2013) pointed to a negative relationship between GDP and financial leverage. While Octavia and Brown (2010) pointed out that GDP growth was a statistically insignificant factor to determine financial leverage.

10. Inflation: Gatsi (2012) noted that inflation represents the rate of change in prices of goods and services during a specific time, which raises interest rate levels and thus banks' lending rates. Trade-Off Theory, Market Timing Theory, and Frank \& Goyal (2008) showed a positive relationship between inflation and leverage. While, Gropp and Heider (2010), does not define the relationship of inflation to the capital structure definitively. Booth et al., (2001) pointed out that inflation leads to an inflation premium on the nominal interest rate, so firms hesitate to borrow, which might cause lower financial leverage.

\section{Methodology}

\subsection{Study Hypotheses}

The study investigated the following Null-Hypothesis:

$\mathrm{H}_{0}$ : There is no statistically significant relationship between the determinants of capital structure and the financial leverage of Jordanian commercial banks.

\subsection{The Study Population and Sample}

The study population comprises all 16 Jordanian banks listed on the Amman Stock Exchange for the period 2008-2017. The sample comprised 13 Jordanian commercial banks. Excluding Islamic banks and banks not listed on the Amman Stock Exchange because of lack of data related to them. In addition, it meets the following conditions:

* All required data to test the variables should be available.

* No merger process occurred in the bank.

* The financial year shall end on 31/12 of each year.

* All financial reports are available to all banks for the period of test and analysis.

* Continuation of listing of the Bank's shares on the Amman Stock Exchange for the period of test and analysis.

The study relied on the following sources to collect data:

1. The annual financial reports issued by the Jordanian Commercial banks.

2. The annual financial reports issued by the Central Bank of Jordan.

3. The annual financial reports issued by the Securities Depository Center.

4. The annual financial reports issued by the Jordanian Department of Statistics.

\subsection{The Mathematical Model}

Based on several previous studies and in proportion to the variables of the study, the equation of multiple linear regression of the determinants of the capital structure in Jordanian commercial banks is:

$\mathrm{FL}_{\mathrm{it}}=\mathrm{a}_{0}+\mathrm{a}_{1} \mathrm{AGE}_{\mathrm{it}}+\mathrm{a}_{2} \mathrm{GDP}_{\mathrm{it}}+\mathrm{a}_{3} \mathrm{GTH}_{\mathrm{it}}+\mathrm{a}_{4} \mathrm{INF}_{\mathrm{it}}+\mathrm{a}_{5} \mathrm{LIQ}_{\mathrm{it}}+\mathrm{a}_{6} \mathrm{PROF}_{\mathrm{it}}+\mathrm{a}_{7} \mathrm{RSK}_{\mathrm{it}}+\mathrm{a}_{8} \mathrm{SZEit}_{+} \mathrm{a}_{9} \mathrm{TANG}_{\mathrm{it}}+\mathrm{a}_{10} \mathrm{TAX}_{\mathrm{it}}+$ e.... (1)

Where

$\mathrm{FL}_{\mathrm{it}}$ : The financial leverage of the fiscal year i for bank $\mathrm{t}$

$\mathrm{AGE}_{\mathrm{it}}$ : The firm age of the fiscal year i for bank $\mathrm{t}$

$\mathrm{GDP}_{\mathrm{it}}$ : The Gross Domestic Product growth rate at current prices of the fiscal year i.

$\mathrm{GTH}_{\mathrm{it}}$ : The growth rate of the fiscal year i for bank $\mathrm{t}$.

$\mathrm{INF}_{\mathrm{it}}$ : inflation rate of the fiscal year $\mathrm{i}$.

$\mathrm{LIQ}_{\mathrm{it}}$ : liquidity rate of the fiscal year i for bank $\mathrm{t}$.

$\mathrm{PROF}_{\mathrm{it}}$ : profitability rate of the fiscal year i for bank $\mathrm{t}$. 
$\mathrm{RSK}_{\mathrm{it}}$ : risk rate of the fiscal year i for bank $\mathrm{t}$.

$\mathrm{SZE}_{\mathrm{it}}$ : The firm size of the fiscal year $\mathrm{i}$.

$\mathrm{TANG}_{\mathrm{it}}$ : tangibility of the fiscal year i for bank $\mathrm{t}$.

$\mathrm{TAX}_{\mathrm{it}}$ : tax rate of the fiscal year i for bank $\mathrm{t}$.

e: error.

3.3.1 Measuring the Study Model Variables

Dependent Variables

The Financial Leverage (FL)

Based on (Kaifeng, 2002; Abbad, 2003). It calculates financial leverage through the following equation:

$\mathrm{FL}=\mathrm{TL}_{\mathrm{it}} / \mathrm{TA}_{\mathrm{it}}$

Where

$\mathrm{TL}_{\mathrm{it}}=$ total liabilities for the fiscal year i for bank $\mathrm{t}$.

$\mathrm{TA}_{\mathrm{it}}=$ total assets for the fiscal year i for bank $\mathrm{t}$.

Independent Variables

1. Size (SZE): Based on (Cassar and Holmes, 2003; Ramadan and Alokdeh, 2011; Anafo et al., 2015). The size calculated through the following equation:

$\mathrm{SZE}=\log \left(\mathrm{TA}_{\mathrm{it}}\right)$

Where

Log = natural logarithm

$\mathrm{TA}_{\mathrm{it}}=$ total assets for the fiscal year i for bank $\mathrm{t}$.

2. Growth (GTH): Based on Amidu (2007). Growth calculated through the following equation:

$\mathrm{GTH}=\left(\mathrm{TAE}_{\mathrm{it}}-\mathrm{TAB}_{\mathrm{it}}\right) / \mathrm{TAB}_{\mathrm{i}}$

Where

$\mathrm{TAE}_{\mathrm{it}}=$ total assets at the end of the fiscal year i for bank $\mathrm{t}$.

$\mathrm{TAB}_{\mathrm{it}}=$ total assets at the beginning of the fiscal year $\mathrm{i}$ for bank $\mathrm{t}$.

3. TAX: Based on Abbad (2013). Tax calculated through the following equation:

Tax $=\left(\mathrm{PBT}_{\mathrm{it}}-\mathrm{PAT}_{\mathrm{it}}\right) / \mathrm{PBT}_{\mathrm{it}}$

Where

PBT $=$ Profit before tax for the fiscal year i for bank $t$.

$\mathrm{PAT}=$ profit after tax for the fiscal year i for bank $\mathrm{t}$.

4. Risk (RSK): Based on (Ramadan and Alokdeh, 2011; Alzubaidi and Salameh, 2014). Risk calculated through the following equation:

$\mathrm{RSK}=\mathrm{S} . \mathrm{D}\left(\mathrm{ROA}_{\mathrm{it}}\right)$

Where

S.D. $=$ Standard Deviation .

$\mathrm{ROA}_{\mathrm{it}}=$ Return On Assets for the fiscal year i for bank $\mathrm{t}$.

5. Age: Based on Ramadan and Alokdeh (2011). Age calculated through the following equation:

Age $=\log \left(\mathrm{Y}_{\mathrm{it}}\right)$

Where

$\log =$ natural logarithm.

$\mathrm{Y}_{\mathrm{it}}=$ years since the bank founded in the fiscal year i for bank $\mathrm{t}$. 
6. Profitability (PROF): Based on (Ramadan and Alokdeh, 2011; Alzubaidi and Salameh, 2014). Profitability calculated through the following equation:

$\mathrm{PROF}=\mathrm{NI}_{\mathrm{it}} / \mathrm{TA}_{\mathrm{it}}$

Where

$\mathrm{NI}_{\mathrm{it}}=$ net income for the fiscal year i for bank $\mathrm{t}$.

$\mathrm{TA}_{\mathrm{it}}=$ total assets for the fiscal year i for bank $\mathrm{t}$.

7. Liquidity (LIQ): Based on (Omet and Mashharawe, 2003; Ramadan and Alokdeh, 2011; Alzubaidi and Salameh, 2014). Liquidity calculated through the following equation:

$\mathrm{LIQ}=\mathrm{CA}_{\mathrm{it}} / \mathrm{CL}_{\mathrm{it}}$

Where

$\mathrm{CA}_{\mathrm{it}}=$ current assets for the fiscal year i for bank $\mathrm{t}$.

$\mathrm{CL}_{\mathrm{it}}=$ current liabilities for the fiscal year $\mathrm{i}$ for bank $\mathrm{t}$.

8. Tangibility (TANG): Based on (Ramadan and Alokdeh, 2001; Omet and Mashharawe, 2003). Tangibility calculated according to the following equation:

$\mathrm{TANG}=\mathrm{FA}_{\mathrm{it}} / \mathrm{TA}_{\mathrm{it}}$

Where

$\mathrm{FA}=$ fixed assets for the fiscal year $\mathrm{i}$ for bank $\mathrm{t}$.

$\mathrm{TA}=$ total assets for the fiscal year $\mathrm{i}$ for bank $\mathrm{t}$.

9. Gross Domestic Product (GDP): Based on Gatsi, (2012). The Gross Domestic Product calculated through the GDP growth rate at current market prices announced by the Department of Statistics.

10. Inflation (INF): Based on Gatsi, (2012). Inflation calculated through annual inflation rates announced by the Department of Statistics.

\section{The Statistical Analysis and Discussion of Results}

\subsection{Descriptive Analysis}

Table 1 below shows the descriptive analysis of all study variables included in the regression model.

Table 1. The Statistical Description of the Variables

\begin{tabular}{cccccccccccc}
\hline $\begin{array}{c}\text { Variables } \\
\text { name }\end{array}$ & $\boldsymbol{F L}$ & $\boldsymbol{A G E}$ & $\boldsymbol{G D P}$ & $\boldsymbol{G T H}$ & $\boldsymbol{I N F}$ & LIQ & PROF & $\boldsymbol{R S K}$ & SZE & TANG & TAX \\
\hline Mean & 0.8566 & 1.584 & 0.0909 & 0.0664 & 0.0327 & 0.323 & 0.0126 & 0.00469 & 9.291 & 0.01806 & 0.295 \\
$\begin{array}{c}\text { Standard } \\
\text { Deviation }\end{array}$ & 0.0263 & 0.1703 & 0.0688 & 0.0778 & 0.0426 & 0.0824 & 0.0048 & 0.000868 & 0.4316 & 0.00851 & 0.0982 \\
\end{tabular}

Based on the results illustrated in Table 1, we note that the size had the highest mean with a value (9.291), while the risk has the lowest mean with a value (0.00469). The financial leverage mean was $(0.8566)$ meaning over $85 \%$ of the bank's capital in the study sample is debt-funded, his shows the importance of debt in the capital financing of the banks, this is consistent with the traditional business nature of commercial banks which rely heavily on deposits.

Also, we can see from the results illustrated in Table 1 , the profitability mean was $(0.0126)$, which shows that the return on assets reached $1.26 \%$. The growth rate mean was $(0.0664)$, this shows that the growth rate reached $6.64 \%$ for the study sample during the examination and analysis periods.

Table 1 reveals that TANG mean was $(0.01806)$ which refers that the fixed assets were $1.806 \%$ of the total assets of the banks. More to add, the RSK mean was (0.00469) meaning a lower risk in the banks, showing that there is no risk of fluctuating net income. Also, LIQ mean was (0.323) which refers that $32.3 \%$ of total assets are liquid assets, this shows the financial solvency of banks and exclusion the exposure to financial distress.

\subsection{Pearson Correlation Analysis}

Table 2 below represents the results of the Pearson Correlation Coefficient to measure any correlation between the variables of the study during the period of the study. 
Table 2. Pearson Correlation between the Variables of the Study

\begin{tabular}{|c|c|c|c|c|c|c|c|c|c|c|c|}
\hline & $L E V$ & $S Z E$ & GRTH & $T A X$ & $R S K$ & $A G E$ & PROF & LIQ & $T A N G$ & $G D P$ & INF \\
\hline LEV & 1 & & & & & & & & & & \\
\hline SZE & 0.111 & 1 & & & & & & & & & \\
\hline GRTH & 0.033 & -0.271 & 1 & & & & & & & & \\
\hline TAX & -0.049 & 0.011 & -0.023 & 1 & & & & & & & \\
\hline RSK & -0.019 & -0.040 & -0.059 & 0.014 & 1 & & & & & & \\
\hline AGE & 0.337 & 0.593 & -0.119 & -0.114 & -0.030 & 1 & & & & & \\
\hline PROF & -0.242 & 0.004 & -0.071 & -0.179 & -0.170 & -0.034 & 1 & & & & \\
\hline LIQ & -0.204 & 0.304 & 0.068 & 0.087 & -0.011 & 0.243 & 0.128 & 1 & & & \\
\hline TANG & 0.057 & -0.391 & 0.109 & -0.027 & 0.109 & -0.115 & -0.190 & -0.336 & 1 & & \\
\hline GDP & -0.086 & -0.159 & 0.069 & -0.125 & -0.208 & -0.154 & 0.244 & 0.341 & -0.065 & 1 & \\
\hline INF & -0.104 & -0.141 & 0.086 & -0.217 & -0.144 & -0.134 & 0.252 & 0.262 & -0.028 & 0.924 & 1 \\
\hline
\end{tabular}

The results in Table 2 show that there is no strong correlation between the study variables, with the highest correlation value (0.337) between the leverage and the bank age, confirming that there is no problem of Multi-Collinearity. There is also a negative correlation of leverage with taxes, risk, profitability, liquidity ratio, GDP, and inflation. While there is a positive correlation of leverage with size, growth, age, and tangible assets. But this is not enough to conclude that there is a Multi-Collinearity problem.

\subsection{Regression Analysis}

Table 3 below shows the results of the regression equation (1) analysis.

Table 3. The Results of Regression Based on: $\mathrm{FL}_{\mathrm{it}}=\mathrm{a}_{0}+\mathrm{a}_{1} \mathrm{AGE}_{\mathrm{it}}+\mathrm{a}_{2} \mathrm{GDP}_{\mathrm{it}}+\mathrm{a}_{3} \mathrm{GRTH}_{\mathrm{it}}+\mathrm{a}_{4} \mathrm{INF}_{\mathrm{it}}+\mathrm{a}_{5} \mathrm{LIQ}_{\mathrm{it}}+\mathrm{a}_{6} \mathrm{PROF}_{\mathrm{it}}+\mathrm{a}_{7} \mathrm{RSK}_{\mathrm{it}}$ $+\mathrm{a}_{8}$ SZEit $+\mathrm{a}_{9}$ TANG $_{\mathrm{it}}+\mathrm{a}_{10} \mathrm{TAX}_{\mathrm{it}}+\mathrm{e} \ldots$.. (1)

\begin{tabular}{ccc|c}
\hline Model & Coefficient & t-Statistic & Prob. \\
\hline (Constant) & -0.2574 & -1.6698 & 0.0979 \\
AGE & 0.2038 & 2.9747 & 0.0036 \\
GDP & -0.1512 & -2.3764 & 0.0193 \\
GRTH & 0.0093 & 0.4601 & 0.6464 \\
INF & -0.1325 & -1.4921 & 0.1386 \\
LIQ & -0.0395 & -1.6668 & 0.0985 \\
PROF & -0.5863 & -1.3164 & .0 .1908 \\
RSK & 2.4812 & 1.3963 & 0.1655 \\
SZE & 0.1550 & 7.8716 & 0.0000 \\
TANG & -0.2647 & -1.0009 & 0.3191 \\
TAX & 0.0015 & 0.1018 & 0.9191 \\
Notes: implies significance at a level of $5 \% ; R^{2}=0.73 ;$ Adj. $R^{2}=0.68$; F-stat. $=13.6 ;$ - -prob. $=0.000$
\end{tabular}

Table 3 shows a statistically significant positive relationship between age and leverage. This shows that older firms finance their projects based on borrowing, because older firms have experience and thus help them build an appropriate financing mix, besides their ability of geographically expand, and also increase customer confidence by improving the type and quality of services provided by them. This supports Trade-Off Theory while it contradicts with the Pecking Order Theory, and (Siam et al., 2005; Ramadan and Alokdeh, 2011).

Table 3 also shows a negative relationship between GDP and leverage. In prosperity periods, GDP rises, creating new lucrative investment opportunities, so individuals and companies with other alternatives to invest will withdraw their deposits or borrow. As a result, banks have to meet the increasing demand for deposits and loans, meaning that banks should rely more on internal sources of financing rather than customer deposits. This results in decreasing leverage. This is consistent with (Nguyen and Kayani, 2013), but It contradicts with (Booth et al., 2001; Gropp and Heider, 2010) and Trade-off theory.

The results in Table 3 also show a positive relationship between growth and leverage. This means that banks that fulfilled high growth rates will need more funds to finance their growth, so they use the money generated from their 
internal sources, and in case these funds are not enough, it will resort to borrowing. Banks with high growth rates have a better and easier chance to get funds because of their good reputation. This supports pecking order theory, trading off theory and consistent with (Michaelas et al., 1999; Booth et al., 2001; Amidu 2007). While it contradicts (Auerbach, 1985; Omet and Mashharawe, 2003; Ramadan and Alokdeh, 2011).

Table 3 also shows a negative relationship between inflation and financial leverage, showing that inflation affects the sample banks. With high inflation, banks are tightening their credit policies to avoid the impact of inflation on interest rates, thus reducing the impact of inflation on the capital structure. This is consistent with (Booth et al., 2001; Ali et al., 2011a; 2011b), while contrary to (Frank and Goyal, 2008; Nguyen and Kayani, 2013), and the trade-off theory and market timing theory.

Based on the results shown in Table 3, there is a negative relationship between the liquidity ratio and the leverage, this enables firms to use this liquidity instead of borrowing from external sources since these firms avoid debt to get rid of the high cost of funds. This is consistent with (Omet and Mashharawe, 2003; Siam et al., 2005; Jong et al., 2008; Ramadan and Alokdeh, 2011; Alzubaidi and Salameh, 2014), and the Pecking Order Theory. But contradicts with the Trade-Off Theory.

Table 3 also shows a negative relationship between profitability and financial leverage, showing that the banks that get profits have a low rate of debt in their capital structure. So the higher the profits, the greater its reliance on internal financing rather than external financing, even if they can get external financing, which leads to a decrease in the debt ratio in the capital structure. These are consistent with Pecking Order Theory and (Myers, 1984; Titman and Wessels, 1988; Barton et al., 1989; Omet and Mashharawe, 2003; Siam et al., 2005; Ramadan and Alokdeh, 2011), but are contradicts with (Modigliani and Miller, 1963; Ooi, 1999; Booth et al., 2001; Amidu 2007; Al-Qudah, 2014).

Table 3 also shows a positive relationship between risk and financial leverage, showing that when financial leverage goes up, the firm risk will increase, which will raise the cost of debt financing. This is consistent with Amidu (2007), but contradicts Trade-Off Theory, Pecking Order Theory, and (Ooi, 1999; Titman and Wessels, 1988; Ramadan and Alokdeh, 2011).

Table 3 also shows a positive relationship between size and financial leverage. This suggests that large firms would use more money from external sources because of insufficient funds generated from internal sources, which leads to a high debt ratio in their capital structure. Also, lenders favor lending large firms because of the availability of their ability in terms of low fluctuation of profits and greater diversity in products and high capacity in debt management, leading to lower levels of risk, so they will be less likely to fail. While Small firms have a low debt ratio because of their reduced ability to provide information to lenders. This is consistent with trading off theory and (Booth et al., 2001; Omet and Mashharawe, 2003; Siam et al., 2005; Amidu 2007; Ali et al., 2011a, 2011b; Al-Qudah, 2014).

Table 3 also shows a negative relationship between asset structure and financial leverage. Thus, the decline in leverage shows a rise in fixed assets and a decrease in operating assets financed by debt. However, a rise in fixed assets does not mean a decrease in risk, also the company's fixed assets have low liquidation or liquid value because not to use them in other companies. This is consistent with Ramadan and Alokdeh (2011), but contradict Pecking Order Theory, Trade-Off Theory and (Feri and Jones, 1979; Marsh, 1982; Van der Wijst and Thurik, 1993; Allen, 1995; Chittenden et al., 1996; Michaelas et al., 1999; Booth et al., 2001; Omet and Mashharawe, 2003).

Table 3 also shows a positive relationship between tax rate and financial leverage, showing that the sample banks did not benefit the tax shield. This is consistent with the traditional theory of capital structure regarding the use of the tax shield and supports the trade-off theory. It contradicts (Graham, 1996; Ramadan and Alokdeh, 2011).

Finally, based on the results in Table 3, we reject the Null-Hypothesis, which states that there is no statistically significant relationship between the determinants of the capital structure and the financial leverage in the Jordanian commercial banks. This shows that there are determinants of the capital structure in the Jordanian commercial banks, as the factors tested could explain $68 \%$ of the change in the capital structure in the Jordanian commercial banks for the period under examination and analysis.

\section{Conclusions}

Given the importance of the banking sector in supporting the economic growth process of any country, and facilitating the transfer of funds between deficit units and surplus units, as the capital structure of the bank affects its stability and its ability to provide liquidity and credit effectively. Therefore, banks must pay attention to solvency and liquidity, and this requires the adoption of correct methods to determine the right capital size and its determinants. Therefore, it was necessary to study the determinants of the capital structure in the Jordanian banks listed on the Amman Stock Exchange, where 13 commercial banks selected out of 16 banks for the period 2008-2017. We performed multiple 
linear regression analysis using e-views software. According to the results of the study, we have shown that over $85 \%$ of Jordanian commercial bank's assets are financing through debts. This confirms the importance of debt in commercial banks' capital structure. Although there have been many studies on capital structure, the capital structure in Jordanian banks is still an important subject of discussion, because of the lack of studies for a clear understanding of the bank's capital structure determinants and factors affecting.

The results illustrate that there was a positive relationship between financial leverage and age, size, risk, growth, and tax; This means that old banks, large banks, and banks that have achieved high growth rates, will need more money to finance their growth operations and if insufficient funds generated from their internal sources will use funds from external sources such as borrowing. This leads to an increase in leverage, high risk, and high cost of debt financing. However, they will be less likely to fail than smaller banks, and this is ultimately consistent with the traditional theory of bank capital structure, and agrees with many previous studies (Booth et al., 2001; Omet and Mashharawe, 2003; Siam et al., 2005; Ramadan and Alokdeh, 2011; Al-Qudah, 2014).

However, the study found that there was a negative relationship between financial leverage and GDP, inflation, liquidity, profitability, and tangibility. This means the rise in GDP will offer new investment opportunities and this leads customers to withdraw their deposits or borrow to enter new investment opportunities, so banks that have a high rate of assets financed from internal sources and in return make good profits will lead to high liquidity, which helps them to meet the needs of its customers than relying on deposits or borrowing. This results in lower leverage and lower cost of funds. Which is consistent with other previous studies (Omet and Mashharawe, 2003; Siam et al., 2005; Ramadan and Alokdeh, 2011; Nguyen and Kayani, 2013).

This study has some limitations. First, this study focused on the Jordanian banking sector, especially the Jordanian commercial banks listed on the Amman Stock Exchange during the period 2008-2017, which may limit the generalization of results to other Jordanian economic sectors. Second, differences from other countries in laws, regulations, and legislation controlling Jordanian commercial banks work, which may affect the determinants of capital structure. Finally, the limited geographical expansion outside Jordan for some Jordanian commercial banks, which may affect the size and determinants of capital.

Finally, although many studies have examined the determinants of capital structure, the subject still raised for further research. Previous literature has shown mixed results, and researchers still cannot determine the best theory explaining the choice of capital structure, and the characteristics of the firm and the economic variables affecting the capital structure. Therefore, I suggest further research and the addition of more potential variables that may affect the capital structure.

\section{References}

AKGÜL, E. \& SİGALI, S. (2018). Determinants of Capital Structure: An Application on BIST Transportation Index. Journal of Accounting \& Finance, 1, 193-215. https://dergipark.org.tr/download/article-file/434958.

Akhavein, J.D., Berger, A.N. \& Humphrey, D.B. (1997). The effect of bank megamergers on efficiency \& prices: evidence from the profit function. Review of Industrial Organization, 12(1), 95-139. https://doi.org/10.1023/A:1007760924829

Allen, M.T. (1995). capital structure determinants in real estate limited partnerships. The Financial Review, 30, 399-426. https://doi.org/10.1111/j.1540-6288.1995.tb00839.x

Al-Qudah, A. (2014). The determinants of capital structure of listed banks in Jordan: Panel data analysis. International Journal of Economics \& Business Research, 8(1), 36-46, http://dx.doi.org/10.1504/IJEBR.2014.063940

Al-Sakran, S.A. (2001). Leverage determinants in the absence of corporate tax system: the case of non-financial publicly traded corporations in Saudi Arabia. Managerial Finance, 27, 58-86. http://dx.doi.org/10.1108/03074350110767583

Al-Singlawi, O. \& Aladwan, M. (2016). Company's characteristics \& capital structure: An Empirical Study on Listed Insurance Companies in Jordan. Journal of Management Research, 8(2), 103-118. http://dx.doi.org/10.5296/jmr.v8i2.9141

Alzubaidi, H. \& Salameh, H. (2014). Testing Some Determinants of Capital Structure: Evidence from Saudi Arabia, Analytical Study (2003-2007). Journal of King Abdulaziz University, Economics \& Administration, 28(1), 27-70. https://ssrn.com/abstract=3328033 
Amidu, M. (2007). Determinants of capital structure of banks in Ghana: an empirical approach. Baltic Journal of Management, 2(1), 67-79. https://doi.org/10.1108/17465260710720255

Anafo, S., Amponteng, E. \& Yin, L. (2015). The Impact of Capital Structure on Profitability of Banks Listed on the Ghana Stock Exchange. Research Journal of Finance \& Accounting, 6(16), 26-35. https://iiste.org/Journals/index.php/RJFA/article/viewFile/24973/25576

ANG, J.S., CHUA, J.H. \& McConnel, J.J. (1982). The administrative cost of corporate bankruptcy: a note. Journal of Finance, 37(1), 219-226. https://doi.org/10.1111/j.1540-6261.1982.tb01104.x

Ashton, D.J. (1991). Corporate financial policy: American analytics \& UK taxation. Journal of Business Finance \& Accounting, 18(4), 465-482. https://doi.org/10.1111/j.1468-5957.1991.tb01116.x

Auerbach, A.J. (1985). Real determinants of corporate leverage, in Freidman, B.M. (Ed.). Corporate Capital Structure in the United States, University of Chicago Press, Chicago, IL, 301-324.

Barclay, M., Smith, C. \& Watts, R. (1995). The Determinants of Corporate Leverage \& Dividend Policies. Journal of Applied Corporate Finance, 7, 4-19. https://doi.org/10.1111/j.1745-6622.1995.tb00259.x

Barton, S.L., Hill, N.C. \& Srinivasan, S. (1989). An empirical test of stakeholder theory predictions of capital. Financial Management, 18(1), 36-44. http://dx.doi.org/10.2307/3665696

Bilgin, R. \& Dinc, Y. (2019). Factoring as a determinant of capital structure for large firms: Theoretical \& empirical analysis. Borsa_Istanbul Review, https://doi.org/10.1016/j.bir.2019.05.001

Booth, Laurence, Varouj Aivazian, Asli Demirgüc-Kunt \& Vojislav Maksimovic. (2001). Capital structures in developing countries. Journal of Finance, 56, 87-130. https://doi.org/10.1111/0022-1082.00320

Brealey, R.A. \& Myers, S.C. (2003). Principles of Corporate Finance, 7th ed., McGraw Hill.

Cassar, G. \& Holmes, S. (2003). Capital structure \& financing of SMEs: Australian evidence. Accounting \& Finance, 43, 123-147. https://doi.org/10.1111/1467-629X.t01-1-00085

Chen, Jean J. Chen., (2004). Determinants of Capital Structure of Chinese-listed Companies. Journal of Business Research, 57(12), 1341-1351. https://doi.org/10.1016/S0148-2963(03)00070-5

Chen, K. (2002). The influence of capital structure on company value with different growth opportunities. Paper of EFMA, Annual Meeting. https://dx.doi.org/10.2139/ssrn.313960

Chittenden, F., Hall, G. \& Hutchinson, P. (1996). Small firm growth, access to interest on corporate capital structure. The Journal of Finance, 8(1), 59-67. https://doi.org/10.1007/BF00391976

Coleman, S. \& Cohn, R. (2000). Small Firms' use of financial leverage: evidence from the 1993 National Survey of Small Business Finances. Journal of Business \& Entrepreneurship, 12(3), 81-98. https://search.proquest.com/openview/481e7504b656c72bc39d56a10bc160dd/1?pq-origsite=gscholar\&cbl=333 12

Diamond, Douglas W. \& Raghuram G. Rajan. (2000). a theory of bank capital. The Journal of Finance, 55, 2431-2465. https://doi.org/10.1111/0022-1082.00296

Fama, E. \& French, K. (2002). Taxes, Financing Decisions \& Firm Value. The Journal of Finance, 53(3), 819-843. https://doi.org/10.1111/0022-1082.00036

Fama, E.F. \& K.R. French. (2002). Testing Tradeoff \& Pecking Order Predictions about Dividends \& Debt. the Review of Financial Studies, 15(1), 01-33. https://doi.org/10.1093/rfs/15.1.1

Feri, M.G. \& Jones, W.H. (1979). Determinants of financial structure: a new methodological approach. The Journal of Finance, 34(3), 631-644. http://doi:10.2307/2327431

Frank, M. \& Goyal, V. (2008). Trade-off \& pecking order theories of debt, in: E. Eckbo (ed.). Hand-book of Corporate Finance: Empirical Corporate Finance, 2, Elsevier, Amsterdam, 135-202. https://doi.org/10.1016/B978-0-444-53265-7.50004-4

Gatsi, J., (2012). Capital Structure of Ghanaian Banks: An Evaluation of its Impact on Performance. the IUP Journal of Bank Management, 11(4), 86-99. https://ideas.repec.org/a/icf/icfjbm/v11y2012i4p86-99.html 
Graham, J.R. (1996). Debt \& the marginal tax rate. Journal of Financial Economics, 41, 41-73. https://doi.org/10.1016/0304-405X(95)00857-B

Graham, J.R. \& Harvey, C.R. (2001). The theory \& practice of corporate finance: evidence from the field. Journal of Financial Economics, 60, 187-243. https://doi.org/10.1016/S0304-405X(01)00044-7

Green, C.J., P. Kimuyu, R. Manos \& V. Murinde. (2002). How Do Small Firms in Developing Countries Raise Capital? Evidence from a Large-Scale Survey of Kenyan Micro \& Smal Scale Enterprises, Finance \& Development Research Programme, Working Paper Series, Paper 47.

Gro R. \& Heider, F. (2010). The determinants of bank capital structure. Review of Finance, 14(4), 587-622. https://doi.org/10.1093/rof/rfp030

Grossman S., J. \& Hart, G. (1982). Corporate financial Structure \& managerial incentives, in: Mcmall, J. (Ed). The Economics of Information \& Uncertainty, University of Chicago. Chicago. http://www.nber.org/chapters/c4434

Harris M. \& Raviv, A. (1990). Capital structure \& the informational role of debt. The Journal of Finance, 45(2), 321-349. https://doi.org/10.1111/j.1540-6261.1990.tb03693.x

Harris, M. \& Raviv, A. (1991). The theory of capital structure. The Journal of Finance, 46(1), $297-355$. https://doi.org/10.1111/j.1540-6261.1991.tb03753.x

Houston, J., James, C. \& Marcus, D. (1997). Capital market frictions \& the role of internal capital markets in banking. Journal of Monetary Economics, 35, 389-411. https://doi.org/10.1016/S0304-405X(97)81511-5

Hutchinson, P. \& Mengersen, K. (1989). The financial profile of growth firms, working paper. University of New England, Armidale, New South Wales.

Iqbal, F., Ahmad, M. \& Ali, H. (2019). Determinants of Capital Structure: An Empirical Study of KSE Listed MNCs in Pakistan. Journal of Accounting, Finance \& Auditing Studies, 5(1), 173-195. http://doi:10.32602/jafas.2019.8

Jensen, Michael C. \& William Meckling. (1976). Theory of the firm: managerial behavior, agency costs \& capital structure, Journal of Financial Economics, 3, 305-360. https://doi.org/10.1016/0304-405X(76)90026-X

Jong, A., Kabir, R. \& Nguyen, T. (2008). Capital Structure around the World: The Roles of Firm \& Country Specific Determinants, Journal of Banking \& Finance, 32(9), 1954-1969. https://doi.org/10.1016/j.jbankfin.2007.12.034

Kashyap, A.K., Rajan, R. \& Stein, J.C. (2002). Banks as liquidity providers: an explanation for the co-existence of lending \& deposit-taking. The Journal of Finance, 57(1), 33-73. https://doi.org/10.1111/1540-6261.00415

Kester, V. (1986). Capital \& Ownership Structure: A Comparison of United States \& Japanese Manufacturing Corporations. Financial Management, 15(1), 5-16. http:// doi.org/10.2307/3665273

KİRACI, K. \& AYDIN, N. (2018). Determinants of Capital Structure: Empirical evidence from traditional Airlines. International Journal of Economic \& Administrative Studies, 21, 173-186. http:// doi.org/10.18092/ulikidince.363126.

Kochhs, R. (1997). Strategic assets, capital structure \& firm performance. Journal of Financial \& Strategic Decisions, 10(3). http://www.studyfinance.com/jfsd/v10n3.html\#kochhar

Lasfer, M. (1999). Debt Structure, Agency Costs \& Firm's Size: An Empirical Investigation., City University, Business School, Working Paper. http://citeseerx.ist.psu.edu/viewdoc/download?doi=10.1.1.32.4477\&rep=rep1\&type=pdf

MacKie-Mason, J.K. (1990). Do taxes affect corporate financing decisions? The Journal of Finance, 45, 1471-1493. https://doi.org/10.1111/j.1540-6261.1990.tb03724.X

Marsh, P. (1982). The choice between equity \& debt: an empirical study. The Journal of Finance, 37(1), $121-144$. https://doi.org/10.1111/j.1540-6261.1982.tb01099.x

Michaelas, N., Chittenden, F. \& Poutziousris, P. (1999). Financial policy \& capital structure choice in UK SMEs: empirical evidence from company panel data. Small Business Economics, 12, 113-130. https://doi.org/10.1023/A:1008010724051

Modigliani, F. \& Miller, M. (1958). The cost of capital, corporation finance \& the theory of investment. American Economic Review, 48(3), 261-297. https://www.jstor.org/stable/1809766

Modigliani, F. \& Miller, M. (1963). Corporate income taxes \& the cost of capital: a correction. American Economic Review, 53(3), 443-453. https://www.jstor.org/stable/1809167 
Mota, J.H.F. \& Moreira, A.C. (2017). Determinants of the capital structure of Portuguese firms with investments in Angola. South African Journal of Economic \& Management Sciences, 20(1), a885. https://doi. org/10.4102/sajems.v20i1.885.

Myers S., C. (2001). capital structure. Journal of Economics Perspective, 15(2), 81-102. http:// doi.org/10.1257/jep.15.2.81

Myers S., C. \& Majluf, N. (1984). Corporate Financing \& Investment Decisions when Firms have Information that Investors do not have. Journal of Financial Economics, 13(2), 187-221. https://doi.org/10.1016/0304-405X(84)90023-0

Myers, S.C. (1977). Determinants of capital borrowing. Journal of Finance Economics, 5(2), 147-175. https://doi.org/10.1016/0304-405X(77)90015-0

Myers, S.C. (1984). The capital structure puzzle. Journal of Finance, 39(3), 575-592. https://doi.org/10.1111/j.1540-6261.1984.tb03646.x

Nguyen, H. \& Kayani, Z. (2013). Determinants of banks' capital structure in Asia - A comparison amongst developed \& developing countries. Master thesis in Business Administration, LUNDS University. https://pdfs.semanticscholar.org/d438/1db8e0c4fd4c29c9df0157031cfe6dcd6811.pdf

Octavia, M. \& Brown, R. (2010). Determinants of bank capital structure in developing countries: Regulatory capital requirement versus the standard determinants of capital structure. Journal of emerging market, 15, 50-62.

Omet, G. \& Mashharawe, F. (2003). The capital structure choice in tax contrasting environments: evidence from the Jordanian, Kuwaiti, Omani \& Saudi corporate sectors. The Economic Research Forum 10th Annual Conference, December (Marrakesh, Morocco). http://citeseerx.ist.psu.edu/viewdoc/download?doi=10.1.1.621.9841\&rep=rep1\&type=pdf

Ooi, J. (1999). The determinants of capital structure: evidence on UK property companies. Journal of Property Investment \& Finance, 17(5), 464-480. https://doi.org/10.1108/14635789910294886

Ozkan, A. (2001). Determinants of capital structure \& Adjustment to long run target: evidence from UK company panel data. Journal of business finance \& accounting, 28(1-2), 175-198. https://doi.org/10.1111/1468-5957.00370

Ramadan, I. \& Alokdeh, S. (2011). Determinants of Capital Structure: Evidence from Jordan (2000 -2006). Jordan Journal of Business Administration, 7(2), 228-245. https://journals.ju.edu.jo/JJBA/article/view/2349

Ramli, N., Latan, H. \& Solovida, G. (2019). Determinants of capital structure \& firm financial performance-A PLS-SEM approach: Evidence from Malaysia \& Indonesia. The Quarterly Review of Economics \& Finance, 71, 148-160. https://doi.org/10.1016/j.qref.2018.07.001

Siam, W., Khrawish, H. \& El-Hammoury, B., (2005). The Capital Structure of Banking Sector in Jordan. Dirasat, Administrative Sciences, 32(1), 196-207. https://journals.ju.edu.jo/DirasatAdm/article/view/1588

Smith, C.W. \& Warner, J.B. (1979). Bankruptcy, secured debt \& optimal capital structure: comment. The Journal of Finance, 34(1), 247-251. https://doi.org/10.1111/j.1540-6261.1979.tb02085.x

Stulz, R.M. \& Johnson, H. (1985). An analysis of secured debt. Journal of Financial Economics, 14(4), 1-19. https://doi.org/10.1016/0304-405X(85)90024-8

Titman, S. \& Wessels, R. (1988). The determinants of capital structure choice. The Journal of Finance, 43(1), 1-19. https://doi.org/10.1111/j.1540-6261.1988.tb02585.x

V. Ilyukhin, E. (2017). The Determinants of Capital Structure: Evidence from Russia. Journal of Corporate Finance Research, 14(4), 54-69. https://doi.org/10.17323/j.jcfr.2073-0438.11.4.2017.54-69

Van der Wijst, N. \& Thurik, R. (1993). Determinants of small firm debt ratios: an analysis of retail panel data. Small Business Economics, 5(1), 55-65. https://doi.org/10.1007/BF01539318 